\title{
MONITORAMENTO DE POLUIÇÃO DE PRAIAS UTILIZANDO PELLETS DE RESINAS PLÁSTICAS EM PORTO SEGURO, BRASIL
}

\author{
AUTOR: LARISSA AMPARO DA FONSECA NO \\ CO-AUTOR/OREINTADOR: SILVIO TAROU SASAKI
}

\begin{abstract}
Resumo: O estudo objetiva identificar a ocorrência dos grânulos plásticos e microplásticos em algumas praias de Porto Seguro, Bahia, como potenciais contaminantes da região. Assim, realizou-se em média 8 coletas em 5 pontos amostrais, com o uso de pinças e bandejas de alumínio, na zona de deixa da última maré alta e próximo aos muros, calçadas ou restinga. Os fragmentos foram separados por tamanho e tipo de resina (polietileno e polipropileno). Houve a predominância de polímeros como o polietileno, embora tenha sido encontrado partículas de polipropileno. $O$ estudo avaliou a concentração dos 16 Hidrocarbonetos Policíclicos Aromáticos (HPAs) prioritários segundo a Agência de Proteção Ambiental dos Estados Unidos (USEPA), considerando apenas os pellets e microplásticos (fragmentos $<5 \mathrm{~mm}$ ) para a análise. A concentração de HPAs variou de 42,7 ng.g-1 a 192,5 ng.g-1 em pellets e 54,7 ng.g-1 a 1659,1 ng.g-1 em microplásticos. As maiores concentrações encontradas, Naftaleno, Fenantreno e Antraceno, podem estar associadas a fontes petrogênicas. Em relação a coloração dos pellets, as maiores concentrações de HPAs, foram observadas nos grânulos mais escuros. Isso corrobora com estudos que avaliam que a quantidade efetiva de contaminantes presentes nos plásticos está consideravelmente associada a coloração, visto que os pellets mais escuros estão a mais tempo no ambiente sofrendo as intempéries e concentrando poluentes. Conclui-se que existe a necessidade de se elaborar políticas públicas que visem monitorar e controlar a presença destas partículas em regiões litorâneas e a dispersão de HPAs nos oceanos, uma vez que os mesmos são responsáveis por causar inúmeros problemas nos ecossistemas marinhos e na saúde humana.
\end{abstract}

Palavras-chave: Pellets, Microplásticos, Poluição invisível, Monitoramento ambiental. 